\title{
Impact of fiddler crabs and plant roots on sediment biogeochemistry in a Georgia saltmarsh
}

\author{
Britta Gribsholt $^{1,3}$, Joel E. Kostka ${ }^{2, *}$, Erik Kristensen ${ }^{1}$ \\ ${ }^{1}$ Institute of Biology, Odense University, University of Southern Denmark, Campusvej 55, 5230 Odense M, Denmark \\ ${ }^{2}$ Department of Oceanography, Florida State University, Tallahassee, Florida 32306-4320, USA \\ ${ }^{3}$ Present address: Center for Estuarine and Marine Ecology, Netherlands Institute of Ecology, PO Box 140, 4400AC Yerseke, \\ The Netherlands
}

\begin{abstract}
The influence of macrofauna and macrophytes on sediment biogeochemistry was quantified in a Spartina alterniflora (Loisel) saltmarsh, with emphasis on sulfur and iron cycling. Vertical profiles of sediment geochemistry and rates of microbial metabolism at 3 sites with different abundances of fiddler crab Uca pugnax burrows, vegetation coverage and hydrology were supplemented with high-resolution radial profiles around burrow walls and S. alterniflora roots. Carbon oxidation was measured as sulfate reduction using the ${ }^{35} \mathrm{~S}$ technique, as total anaerobic $\mathrm{CO}_{2}$ production, and as Fe(III) reduction by monitoring Fe(II) evolution. Depth-integrated (0 to $10 \mathrm{~cm}$ ) sulfate reduction was $25 \%$ lower, while total Fe and Fe(III) concentrations were 1.5 and 6 times higher, respectively, in bioturbated than in nonbioturbated sediment. Low sulfate-reduction rates adjacent to burrow walls ( $3 \%$ of those in bulk sediment) were counteracted by very high Fe(III) reduction rates. Thus, Fe(III) reduction accounted for 54 to $86 \%$ of the total carbon oxidation within $4 \mathrm{~cm}$ distance of burrows, decreasing in importance with distance from the burrow wall. Overall, S. alterniflora roots showed a greater impact on sediment biogeochemistry than crab burrows. Sulfate reduction was almost absent in the rhizosphere, whereas Fe(III) reduction rates $\left(6.2 \mu \mathrm{mol} \mathrm{Fe} \mathrm{cm}^{-3} \mathrm{~d}^{-1}\right)$ were among the highest reported for marine sediments, accounting for $>99 \%$ of carbon oxidation. Our results confirm the universal relationship between the contribution of Fe(III) respiration to total carbon oxidation and solid Fe(III) concentrations that has been suggested based on studies of subtidal marine sediments. The importance of $\mathrm{Fe}(\mathrm{III})$ respiration was strongly dependent on $\mathrm{Fe}(\mathrm{III})$ concentrations below levels of $30 \mu \mathrm{mol} \mathrm{cm}{ }^{-3}$, whereas above this level almost all anaerobic respiration was mediated by Fe(III) reduction in saltmarsh sediments.
\end{abstract}

KEY WORDS: Carbon oxidation - Bioturbation - Fe(III) reduction - Root oxidation - Spartina alterniflora $\cdot$ Sulfate reduction $\cdot$ Uca pugnax

Resale or republication not permitted without written consent of the publisher

\section{INTRODUCTION}

Salt marshes are areas of intense biogeochemical cycling driven by high rates of primary production (Mitsch \& Gosselink 1993). The interactions between marsh plants and sediment biogeochemistry are complex, with several interrelated mechanisms and processes (Giblin \& Howarth 1984, Hines et al. 1989). The majority of the production by the halophyte Spartina alterniflora in saltmarshes along the east coast of North America occurs below ground, and dead roots and rhizomes are major sources of organic carbon for microbial metabolism (Howarth 1993). A large part of this organic carbon pool is relatively refractory, and thus inaccessible to many anaerobic bacteria. Living roots and rhizomes, however, also supply organic matter to the sediment through root excretion of dissolved organic carbon and fermentation products from anaerobic root metabolism (Hines et al. 1989). This labile pool can readily be utilized by anaerobic bacteria, such as sulfate reducers (Hines et al. 1999, Gribsholt \& Kristensen 2002b). Sulfate reduction, which is considered 
to be the dominant microbial respiration process in marshes (Hines et al. 1989, Alongi 1998), responds quickly to changes in root excretion of dissolved organic carbon (Hines et al.1999). Enhanced rates of sulfate reduction have been observed in the rhizosphere of various marine macrophytes (Isaksen \& Finster 1996, Hansen et al. 2000, Nielsen et al. 2001, Gribsholt \& Kristensen 2003).

In addition to acting as a source of organic matter to the sediment, Spartina alterniflora creates a mosaic of oxic and oxidized microniches rich in Fe(III) around roots via oxygen translocation across the root surface into the surrounding sediment (Sundby et al. 1998, Holmer et al. 2002). Microbial reduction of Fe(III) formed around roots may therefore contribute to the carbon cycling in saltmarsh sediments (Jacobson 1994, Kostka \& Luther 1995, Kostka et al. 2002a). This has been confirmed by the presence of active ironreducing bacteria associated with aquatic macrophytes, including S. alterniflora (King \& Garey 1999, Lowe et al. 2000, Kostka et al. 2002a). Differentiated and enhanced benthic mineralization due to more oxidized redox conditions and increased substrate availability has been found recently in marsh sediments vegetated by Spartina anglica (Gribsholt \& Kristensen 2002a, 2003) as well as in mangrove and seagrass areas (Holmer et al. 1999).

Sediment-dwelling infauna are a ubiquitous component of saltmarshes in North America, with fiddler crabs (Uca spp.) being the most abundant and conspicuous group in Spartina alterniflora marshes (Bertness 1985). The distribution of fiddler crabs within saltmarshes varies considerably, and they occur most frequently on creek banks and in 'tall' and 'medium' stands of S. alterniflora. Fiddler crabs excavate and maintain semi-permanent burrows in the marsh, which can potentially enhance sediment drainage and oxidation level (Howes et al. 1981, Montague 1982, Bertness 1985). The burrows generally extend from 3 to $25 \mathrm{~cm}$ into the sediment and may exceed abundances of 500 ind. $\mathrm{m}^{-2}$ (Taylor \& Allanson 1993). The continuously changing spatial heterogeneity and physical conditions created by burrowing activities of fiddler crabs may affect the dynamics of organic matter decomposition in marshes. Sediment from oxic surface layers is buried into anoxic zones and vice versa during burrow excavation, transferring labile substrates to starved anaerobic bacteria and refractory substrates to efficient aerobic bacteria (Montague 1982, Kranzberg 1985, Kristensen \& Holmer 2001).

Burrow structures enlarge the area of oxic interfaces of saltmarsh sediments by 20 to $60 \%$ or more (Montague 1982). The intrusion of oxygen enhances aerobic decomposition (Katz 1980), increases the volume of oxidized Fe(III)-containing sediment, and neutralizes toxic metabolites from anaerobic processes (e.g. sulfide). Fiddler crabs not only stimulate microbial activity and metabolism in the sediment (Taylor \& Allanson 1993), they may also affect the partitioning between electron acceptors (e.g. sulfate vs Fe[III]) used by anaerobic bacteria in the terminal oxidation of organic carbon (Kostka et al. 2002a). Despite their high abundance in saltmarshes, little attention has been directed towards an understanding of the ecological role of fiddler crabs, including their effects on carbon oxidation within the sediments.

Here we further elucidate the impacts of fiddler crab burrows and plant roots on sediment biogeochemistry through radial profiling of the burrow wall and rhizosphere. The emphasis of our studies was on sulfate reduction and $\mathrm{Fe}$ (III) reduction since these 2 processes are considered most important for terminal carbon oxidation in saltmarsh sediments (Lowe et al. 2000, Kostka et al. 2002b). Sediment geochemistry as well as microbial rate measurements associated with macrobenthic structures were conducted in vertical and radial profiles at sites with variable abundances of macrobenthic organisms. Our high-resolution results document the dramatic effects burrows and roots have on saltmarsh sediment geochemistry. The Fe cycle is stimulated to such an extent that microbial Fe(III) reduction almost completely outcompetes sulfate reduction around crab burrows and in rhizospheres.

\section{MATERIALS AND METHODS}

Study area. The study was conducted at the Saltmarsh Ecosystem Research Facility (SERF) of the Skidaway Institute of Oceanography on Skidaway Island, Georgia (Fig. 1). The SERF marsh is dominated by monospecific stands of the halophyte Spartina alterniflora (Loisel). Short forms dominate the interior platform of the marsh, while the levees adjacent to creeks are vegetated by tall forms of $S$. alterniflora. The fiddler crab Uca pugnax is abundant throughout the marsh. The marsh is influenced by semidiurnal tides, with a maximum range of about $2 \mathrm{~m}$.

Sediment samples were collected from 3 sites differing in abundance of macroorganisms: (1) an unvegetated creekbank without fiddler crabs (non-bioturbated unvegetated creek bank, NUC), (2) an unvegetated creekbank with fiddler crabs (bioturbated unvegetated creek bank, BUC) and (3) a vegetated levee with tall stands of Spartina alterniflora and fiddler crabs (bioturbated vegetated levee, BVL) (Fig. 1). NUC and BUC were selected at the same elevation, while BVL was located at about $0.5 \mathrm{~m}$ higher elevation, and consequently was air-exposed for longer periods of time. Since the crab burrows at BUC generally were 
variable in size, shape and depth, care was taken to select burrows of approximately similar diameter. Only isolated burrows some distance from roots were sampled on the levee. Samples were collected during low tide on 2 sampling occasions, October 26 to 28, 1999 and August 1 to 5, 2000. Sediment temperature was $\sim 20$ and $30^{\circ} \mathrm{C}$ and the salinity of tidal creek water was 20 and 33 in October and August, respectively.

Flora and fauna. All fiddler crab burrows at the bioturbated creek bank (BUC) and at the levee (BVL) were counted within 10 randomly chosen quadrats $(25 \times 25 \mathrm{~cm})$ in August, and the burrow diameter at the sediment surface was measured. The maximum height of all plant shoots within 10 quadrats $(25 \times 25 \mathrm{~cm})$ was measured in August. The below-ground plant biomass in the top $10 \mathrm{~cm}$ sediment was determined in October by washing $1 \mathrm{~cm}$ sediment sections over a $1 \mathrm{~mm}$ mesh. Root and rhizome dry weight (DW) was obtained after drying at $65^{\circ} \mathrm{C}$ for $24 \mathrm{~h}$.

Sediment sampling. Triplicate sediment cores for determination of vertical profiles of solid-phase and porewater constituents were collected at each site by gently pushing Plexiglas tubes (i.d. $=4.8 \mathrm{~cm}$ ) into the sediment. Simultaneously, 3 cores for determining sulfate reduction rates (SRR) were sampled by inserting smaller tubes (i.d. $=2.2 \mathrm{~cm}$ ). All tubes were sealed with butyl rubber stoppers and dug out of the sediment. Care was taken to avoid coring too close to burrows or large roots. All sediment cores were kept cool $\left(4^{\circ} \mathrm{C}\right)$ until processing (within $5 \mathrm{~h}$ ).

Sediment for high-resolution radial profiles of solidphase and porewater constituents, sulfate reduction and anaerobic $\mathrm{CO}_{2}$ production (jars) near burrows were collected according to the technique of Hansen et al. (1996). After exposing a burrow wall, radial minicores $(1.2 \mathrm{~cm}$ in diameter) were obtained $5 \mathrm{~cm}$ below the sediment surface by gently inserting a $10 \mathrm{~cm}^{3}$ 'cutoff' syringe 5 to $6 \mathrm{~cm}$ horizontally into the sediment. Cores for radial burrow sampling were obtained at the creek bank (BUC burrows) as well as on the levee (BVL burrows). Radial mini-cores of sediment in the root zone of tall Spartina alterniflora plants were collected in a similar manner to radial burrow samples after exposing a vertical section of the rhizosphere directly below a large plant.

Solid-phase iron and sediment characteristics. Vertical profiles of solid-phase iron were measured in the sediment remaining after porewater extraction, whereas separate mini-cores were used for iron analysis in the radial sampling. Wet chemical extractions were used to determine the poorly crystalline Fe-oxide minerals. Iron was extracted in $0.5 \mathrm{M} \mathrm{HCl}$ for $1 \mathrm{~h}$ (Kostka \& Luther 1994). The oxidation state of Fe in the extract was further determined by analysis in (1) ferrozine buffer (50 mM HEPES, $0.1 \%$ ferrozine,

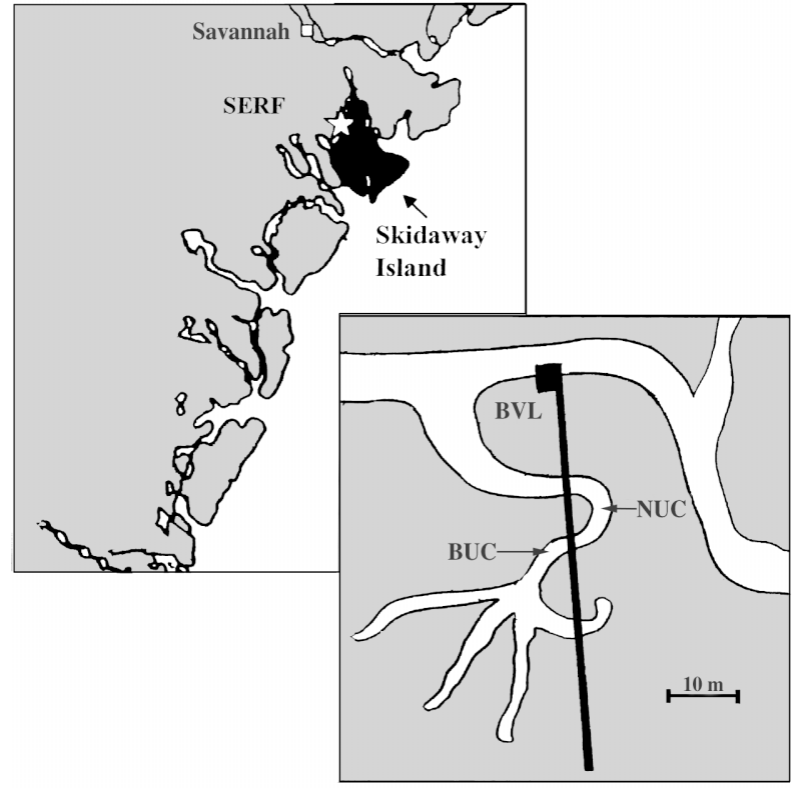

Fig. 1. Map of coast of Georgia, USA, showing Saltmarsh Ecosystem Research Facility (SERF study site (价) and sampling stations (inset) along the boardwalk across the saltmarsh (NUC: non-bioturbated unvegetated creek bank; BUC: bioturbated unvegetated creek bank; BVL: bioturbated vegetated levee)

$\mathrm{pH} 7$ ), and (2) ferrozine buffer $+1 \%(\mathrm{w} / \mathrm{v})$ hydroxylamine hydrochloride ( $\mathrm{pH}$ 7). Iron determined in the $\mathrm{HCl}$ extract with hydroxylamine addition is operationally defined as the total $\mathrm{HCl}$-extractable fraction $(\mathrm{Fe}[\mathrm{II}]+\mathrm{Fe}[\mathrm{III}])$, while $\mathrm{Fe}$ in the $\mathrm{HCl}$ extract without hydroxylamine addition is defined as the $\mathrm{HCl}$ extractable Fe(II). Solid Fe(III) was determined by difference between these 2 fractions. Calibration experiments with pure Fe phases have confirmed the selectivity of this extraction towards poorly crystalline or amorphous Fe-oxide minerals (Kostka \& Luther 1994).

Sediment density was obtained from the wet weights of known sediment volumes. Water content and organic content (loss on ignition, LOI) was determined as weight loss after drying at $105^{\circ} \mathrm{C}$ and subsequent combustion at $520^{\circ} \mathrm{C}$ for $6 \mathrm{~h}$, respectively. Particulate organic carbon (POC) and particulate organic nitrogen (PON) of dried samples were determined with a Carlo Erba Elemental Analyser EA 1100A after the method of Kristensen \& Andersen (1987).

Radial profiles of temperature and $\mathrm{pH}$ from the burrow walls and in the bulk sediment were measured in situ at BUC and BVL in August by inserting a temperature probe and a pH glass electrode calibrated with NBS standards (National Bureau of Standards, Gaithersburg, USA) directly into the sediment. 
Porewater extraction and analysis. Sediment cores for porewater extraction were sectioned into $1 \mathrm{~cm}$ intervals to $10 \mathrm{~cm}$ depth for vertical profiles. Radial mini-cores from October were sectioned into $5 \mathrm{~mm}$ intervals to a distance of $10 \mathrm{~mm}$, followed by $10 \mathrm{~mm}$ sections to a distance of $40 \mathrm{~mm}$, whereas those from August were sectioned into $0-3,3-6,6-9,9-12$, $12-15,15-20,20-30$ and $30-40 \mathrm{~mm}$ intervals from the burrow wall. Rhizosphere and bulk levee profiles were not sub-sectioned but were otherwise treated similarly. Porewater was obtained by centrifugation (10 min, $5000 \times g$ ) and filtered through $13 \mathrm{~mm}$ Gelman acrodisc nylon filters before analysis of $\mathrm{SO}_{4}{ }^{2-}, \mathrm{Fe}^{2+}, \mathrm{H}_{2} \mathrm{~S}$, total $\mathrm{CO}_{2}$, $\left(\mathrm{TCO}_{2}\right)$ and dissolved organic carbon (DOC). All sediment-sectioning, manipulation, and porewater sectioning was carried out under strictly anoxic conditions in a nitrogen-filled glove bag.

$\mathrm{SO}_{4}{ }^{2-}$ in acidified $(\mathrm{pH}<3$ with $\mathrm{HCl}$ ) porewater was analyzed using the turbidometric method of Tabatabai (1974). Dissolved $\mathrm{Fe}^{2+}$ was determined spectrophotometrically on $\mathrm{HCl}$-acidified ( $\mathrm{pH} \sim 2$ ) samples after complexation with ferrozine $(0.02 \%$ in $50 \mathrm{mM} \mathrm{HEPES}$, $\mathrm{pH} 7$ ) according to Stookey (1970). Sulfide was analyzed according to the method of Cline (1969). Porewater for the determination of $\mathrm{TCO}_{2}$ were stored in $1.8 \mathrm{ml}$ glass vials capped with Teflon-coated butyl rubber septa, to exclude any gas phase and to maintain anoxia. Samples were stored at $4^{\circ} \mathrm{C}$ and analyzed for $\mathrm{TCO}_{2}$ within a few days by the flow injection/diffusion cell technique of Hall \& Aller (1992). DOC was analyzed on a Shimadzu TOC-5000 total organic carbon analyzer after acidification with $2 \mathrm{M} \mathrm{HCl}(\mathrm{pH}<3)$ to remove dissolved inorganic carbon. Burrow and creekwater samples were treated in a similar manner to the porewater, except that no analysis of $\mathrm{H}_{2} \mathrm{~S}$ and DOC was performed.

Burrow-water sampling. Burrow water was sampled by withdrawing water into a $60 \mathrm{ml}$ syringe via $3 \mathrm{~mm}$ silicone tubing gently pushed 4 to $6 \mathrm{~cm}$ into a burrow. Burrow water was sampled at $1 \mathrm{~h}$ intervals after exposure of the sediment during receding tides in October, and stored for later determination of dissolved $\mathrm{SO}_{4}{ }^{2-}$, $\mathrm{Fe}^{2+}$ and $\mathrm{TCO}_{2}$ as described above. However, most burrows were rapidly drained of water at the onset of low tide, and only about $20 \%$ of the burrows at the levee (BVL) and even less at BUC contained sufficient water for sampling. Although burrow-water time series were available from the levee, the data was pooled as there was no significant difference over time for any of the parameters examined. At BUC, sufficient burrow water for analysis was obtained only once. Outgoing and incoming tidal water was collected directly from the main creek for comparative purposes.

Sulfate reduction assay. Vertical profiles of sulfate reduction rates (SRR) were determined by the core- injection technique (Jørgensen 1978). Volumes of $2 \mu \mathrm{l}$ radiolabeled sulfate $\left({ }^{35} \mathrm{~S}_{-} \mathrm{SO}_{4}{ }^{2-}, 60 \mathrm{kBq}\right)$ were injected through silicone-filled ports at $1 \mathrm{~cm}$ intervals down to $10 \mathrm{~cm}$ depth. Cores were incubated for $2.5 \mathrm{~h}$ in the dark at in situ temperatures. The incubations were terminated and sulfide was preserved by slicing the sediment at $1 \mathrm{~cm}$ depth intervals directly into $50 \mathrm{ml} \mathrm{screw-}$ capped plastic centrifuge tubes containing $5 \mathrm{ml}$ of $20 \%$ (w/w) zinc acetate solution. The tubes were vigorously shaken and stored frozen until analysis.

Radial profiles of SRR were made by line-injection of $10 \mu \mathrm{l}$ radiolabeled sulfate $\left({ }^{35} \mathrm{~S}_{-} \mathrm{SO}_{4}{ }^{2}, 300 \mathrm{kBq}\right)$ along the central axis of radial mini-cores. Samples were incubated for $2.5 \mathrm{~h}$ in the dark at 20 and $30^{\circ} \mathrm{C}$ in October and August, respectively. The incubations were terminated by transferring the syringes directly onto dry ice, which quickly froze the sediment. Sediment samples were later extruded while still frozen, and were sectioned as described above for the porewater extractions. The sediment slices were transferred directly into $\mathrm{ZnAc}(20 \% \mathrm{w} / \mathrm{w})$. The reduced ${ }^{35} \mathrm{~S}$ was recovered from the ZnAc preserved sediment from both vertical and radial profiles by distillation according to the 2step procedure of Fossing \& Jørgensen (1989) followed by radiocounting of subsamples from the distillation traps. The total reducible inorganic sulfur pools (TRS) was determined as sulfide in the distillation traps by the Cline method described above for porewater.

Anaerobic jar incubations. Anaerobic carbon mineralization rates in radial profiles from fiddler crab burrows at the creek bank (BUC) and in cross-sections at $5 \mathrm{~cm}$ sediment depth through the rhizosphere and the bulk levee sediment were determined in August. A total of 150 radial mini-cores were collected from burrows at the creek bank, while only 15 radial mini-cores were obtained from both the levee rhizosphere and the bulk levee sediment. All cores were stored cold on ice immediately after collection. Mini-cores from the creek bank burrows were sectioned under nitrogen as described above for the August porewater extraction, and the sediment from each interval was pooled and mixed thoroughly. Mini-cores from the rhizosphere and bulk levee were pooled and mixed after discarding $5 \mathrm{~mm}$ sediment at either end of the core. The homogenized sediment of each mixture was transferred into twelve $4 \mathrm{ml}$ glass vials (jars) which were capped leaving no headspace, and incubated in the dark at $30^{\circ} \mathrm{C}$. After $0,12,24,48,96$ and $160 \mathrm{~h}$ centrifugation $(5000 \times g, 10 \mathrm{~min})$ for 2 jars of each type were sacrificed to obtain porewater. After filtration through $13 \mathrm{~mm}$ Gelman acrodisc nylon filters, $110 \mu \mathrm{l}$ of the porewater was transferred to a $450 \mu \mathrm{l}$ glass vial containing $330 \mu \mathrm{l}$ distilled water and $10 \mu \mathrm{l}$ saturated $\mathrm{HgCl}_{2}$ solution and capped with Teflon-coated butyl rubber septa leaving no headspace. Samples were stored at 
$4^{\circ} \mathrm{C}$ and analyzed for $\mathrm{TCO}_{2}$ within 1 mo as described above. The remaining porewater was acidified $(\mathrm{HCl})$ for later determination of dissolved $\mathrm{Fe}^{2+}$ as described above. The sediment was then homogenized and solidphase Fe(II) was extracted and analyzed as described above. All sediment and porewater handling associated with jars were done under $\mathrm{N}_{2}$ atmosphere. Reaction rates in jars were calculated from a linear fit of concentration changes as a function of time.

\section{RESULTS}

\section{Sediment and porewater properties}

Sediment from the non-bioturbated creek bank (NUC) consisted of fine silt with an upper, $1 \mathrm{~cm}$ thick, brownish oxidized zone. Below this depth, the reduced sediment was homogeneously greyish-black. The infauna was sparse and consisted of occasional polychaetes of the genus Nereis. In the bioturbated creek bank site (BUC), the sediment between fiddler crab burrows was heterogeneous grey-brownish in appearance, whereas the burrows were coated by a several $\mathrm{mm}$ thick oxidized zone. Sediment from the levee (BVL) appeared oxidized, and was a brownish color deep down, but with many black spots. The sediment in the rhizosphere directly below large plants was highly oxidized and red iron-oxide coatings were evident on the roots.

Fiddler crab burrows were smaller and more abundant at BVL than at BUC (Table 1). Burrow density was not quantified in October but based on visual observations it appeared to be lower than in August. The 'tall' Spartina alterniflora at BVL was $138 \pm 17 \mathrm{~cm}$ tall in October and occurred at a density of $\sim 95$ plants $\mathrm{m}^{-2}$. The root and rhizome biomass at BVL (between plants) increased with depth to $10 \mathrm{~cm}$, while no roots and rhizomes (living or dead) were observed in the creekbank sediments (NUC and BUC).

Porosity and water content were similar at the 3 sites, but with an elevated trend at NUC (Table 2). Radial profiles showed that water content was 2 to $9 \%$ higher near the burrows than in sediment away from them (Fig. 2A). The water content at $5 \mathrm{~cm}$ depth in the rhizosphere, on the other hand, was 6 to $8 \%$ lower than in the bulk sediment between plants (data not shown). Particulate organic carbon and nitrogen content in bulk sediment was $25 \%$ lower at BUC than at the other sites, whereas BVL exhibited the highest molar C:N ratio. LOI at NUC and BUC
Table 1. Diameter $(\mathrm{mm})$ and density $\left(\mathrm{m}^{-2}\right)$ of Uca pugnax burrows and Spartina alterniflora shoot density at the 3 sampling sites (NUC: non-bioturbated unvegetated creek bank; BUC: bioturbated unvegetated creek bank; BVL: bioturbated vegetated levee) in August 2000. Root biomass ( $\mathrm{g} \mathrm{m}^{-3}$ ) was determined in October 1999 (mean $\pm \mathrm{SD}, \mathrm{n}=10)$

\begin{tabular}{|lcccc|}
\hline \multirow{2}{*}{ Site } & \multicolumn{2}{c}{ Uca pugnax burrows } & \multicolumn{2}{c|}{$\begin{array}{c}\text { S. alterniflora } \\
\end{array}$} \\
& Diameter & Density & Density & Root biomass \\
\hline NUC & - & 0 & 0 & 0 \\
BUC & $17.4 \pm 9.9$ & $280.8 \pm 70.5$ & 0 & 0 \\
BVL & $12.7 \pm 7.7$ & $342.9 \pm 95.8$ & $91.4 \pm 33.7$ & $96.9 \pm 48.3$ \\
& & & & \\
\hline
\end{tabular}

was similar at a level 10 to $30 \%$ lower than at BVL. A high variation in LOI at the innermost $1.5 \mathrm{~cm}$ of the radial burrow profiles (Fig. 2B) coincided with slightly elevated POC as well as the molar $\mathrm{C}: \mathrm{N}$ ratio (10 to $20 \%$ ) at BVL (Fig. 2C,D). Rhizosphere organic matter content, measured as POC and PON, was 25 to $30 \%$ lower than the bulk levels, whereas the molar $\mathrm{C}: \mathrm{N}$ ratio was highest in the rhizosphere. Porewater $\mathrm{pH}$ was substantially lower (by $\sim 1 \mathrm{pH}$ unit) at the vegetated than at the unvegetated sites (Table 2). While $\mathrm{pH}$ was even further reduced in the rhizosphere, it appeared to be elevated around burrow walls compared to bulk sediment (Fig. 2F). Radial profiles of sediment temperature, on the other hand, increased with increasing distance from burrows (Fig. 2E).

\section{Sulfate reduction}

SRR was highest near the surface and gradually decreased with depth at NUC (Fig. 3A), whereas the 2 other sites had subsurface maxima at 1 to $3 \mathrm{~cm}$ depth followed by constant or slightly decreasing levels below this (Fig. 3B,C). Depth-integrated (0 to $10 \mathrm{~cm}$ ) sulfate reduction rates showed an inverse relationship with abundance of macroorganisms in October. High-

Table 2. Sediment characteristics in vertical cores $(0$ to $10 \mathrm{~cm})$ at non-bioturbated unvegetated creek bank (NUC), bioturbated unvegetated creek bank (BUC) and the bioturbated vegetated levee (BVL) and through the rhizosphere Spartina alterniflora at 5 to $6 \mathrm{~cm}$ depth in October 1999. $\mathrm{pH}$ was measured in August 2000 (mean $\pm \mathrm{SD}, \mathrm{n}=3$ to 5). LOI: loss on ignition

\begin{tabular}{|lcccc|}
\hline & NUC & BUC & BVL & Rhizosphere \\
\hline Water content $(\%)$ & $72.2 \pm 1.0$ & $67.3 \pm 1.4$ & $67.6 \pm 0.8$ & $63.1 \pm 3.1$ \\
pH & $7.2 \pm 0.3$ & $7.0 \pm 0.1$ & $6.4 \pm 0.3$ & $5.4 \pm 0.0$ \\
Porosity & $0.82 \pm 0.01$ & $0.78 \pm 0.02$ & $0.78 \pm 0.01$ & - \\
LOI $(\%)$ & $12.5 \pm 0.4$ & $12.2 \pm 0.7$ & $14.9 \pm 0.6$ & $12.8 \pm 0.6$ \\
POC $\left(\mathrm{mmol} \mathrm{cm}^{-3}\right)$ & $10.2 \pm 1.1$ & $7.4 \pm 0.8$ & $10.1 \pm 0.4$ & $7.5 \pm 0.3$ \\
PON $\left(\mathrm{mmol} \mathrm{cm}^{-3}\right)$ & $0.82 \pm 0.07$ & $0.60 \pm 0.07$ & $0.77 \pm 0.04$ & $0.53 \pm 0.09$ \\
C:N & $12.4 \pm 0.6$ & $12.4 \pm 0.4$ & $13.2 \pm 0.4$ & $14.0 \pm 0.3$ \\
& & & & \\
\hline
\end{tabular}



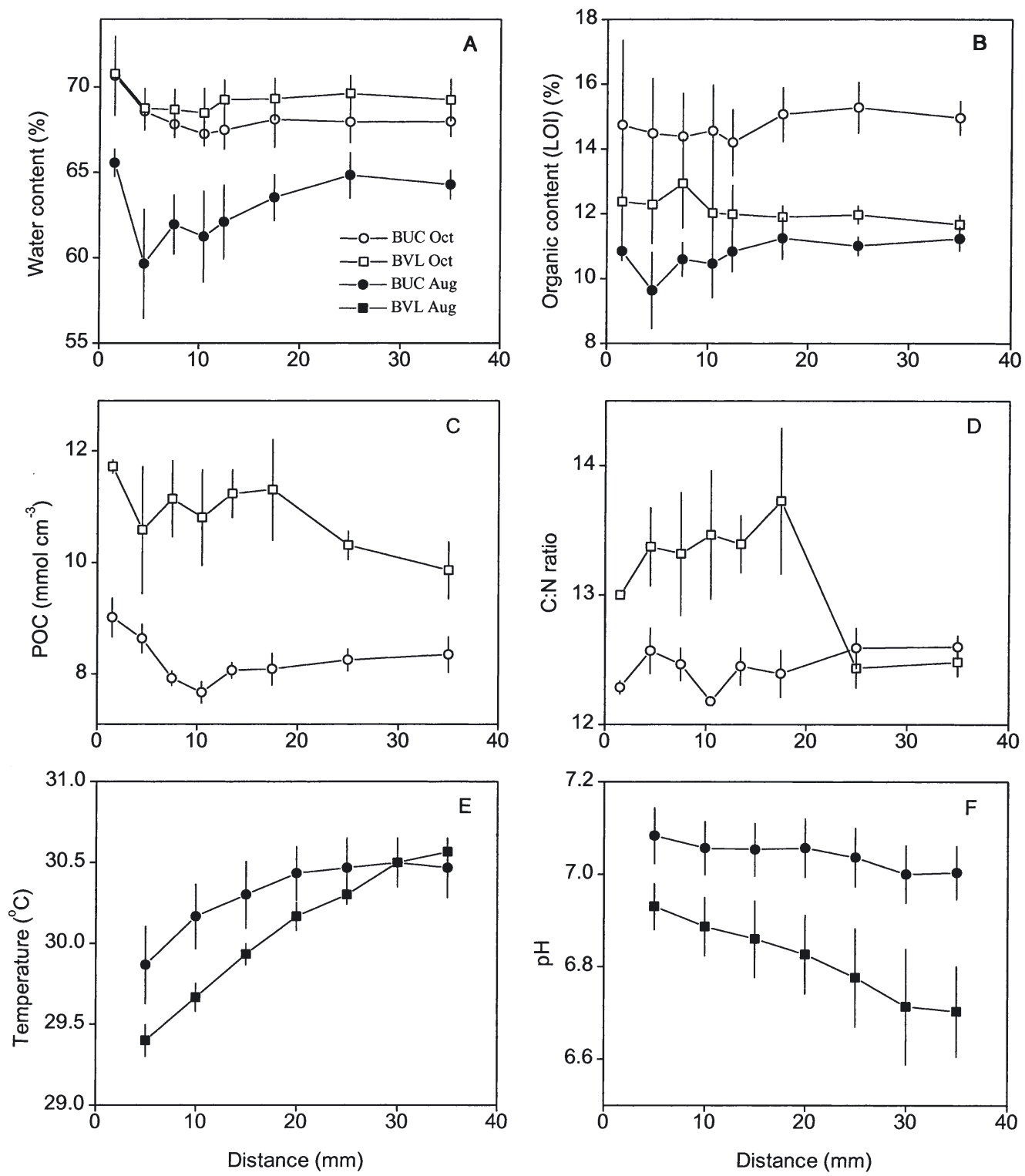

Fig. 2. Sediment characteristics in radial profiles from fiddler crab Uca pugnax burrow walls into bulk sediment at $5 \mathrm{~cm}$ depth (Distance $=$ distance from burrow walls). Burrows were sampled at the levee (BVL) and creek bank (BUC) in October 1999 and August 2000 (Mean $\pm \mathrm{SD}, \mathrm{n}=4$ to 5). LOI: loss on ignition

est rates were observed at NUC, intermediate at BUC and lowest at BVL (Table 3). A seasonal difference was observed, with considerably lower $(41 \%)$ rates at NUC in August.

SRR was 32 and 18 times higher in the bulk BUC and BVL sediment, respectively, than adjacent $(3 \mathrm{~mm})$ to the burrow walls in October, while the difference at BUC in August only was 4 times (Fig. 4A). The slope of increase along the radial profiles was highest within 1 to $2 \mathrm{~cm}$ of the burrow wall, approaching bulk sediment levels at 3 to $4 \mathrm{~cm}$ distance. Sulfate reduction was greatly reduced in the rhizosphere (25 to $130 \mathrm{nmol}$
$\mathrm{SO}_{4}{ }^{2-} \mathrm{cm}^{-3} \mathrm{~d}^{-1}$ ) compared to the bulk levee sediment (380 to $460 \mathrm{nmol} \mathrm{SO}{ }^{2-} \mathrm{cm}^{-3} \mathrm{~d}^{-1}$ ) (Fig. 5B). However, the rhizosphere rates were $>400 \%$ higher in October than in August, while an opposite trend (21\%) was observed for the bulk levee sediment (data not shown).

\section{Reaction rates in anoxic jars}

The concentration of porewater $\mathrm{TCO}_{2}$ and solid-phase Fe(II) generally increased in a linear fashion in all jar incubations during the anoxic incubation, with a con- 
comitant accumulation of dissolved $\mathrm{Fe}^{2+}$ (Fig. 6). The data obtained within the first $24 \mathrm{~h}$ were not included in the regressions used for $\mathrm{TCO}_{2}$ and $\mathrm{Fe}(\mathrm{II})$ rate determination due to disturbance of the sediment during homogenization (Kristensen et al. 2000). Total carbon mineralization rate $\left(\mathrm{TCO}_{2}\right.$ production) decreased with increasing distance within the first $2 \mathrm{~cm}$ from burrow walls, followed by a slight increase 3 to $4 \mathrm{~cm}$ away (Fig. 5A). The Fe(III) reduction rate, determined as the inverse of the $\mathrm{Fe}$ (II) accumulation rate was highest (up to $6 \mu \mathrm{mol} \mathrm{cm}{ }^{-3}$ ) 0 to $1 \mathrm{~cm}$ adjacent to the burrow wall, and decreased substantially (40\%) further away (Fig. 5A). The accumulation of dissolved $\mathrm{Fe}^{2+}$ in the bulk levee sediment was similar to the increase observed at BUC, while

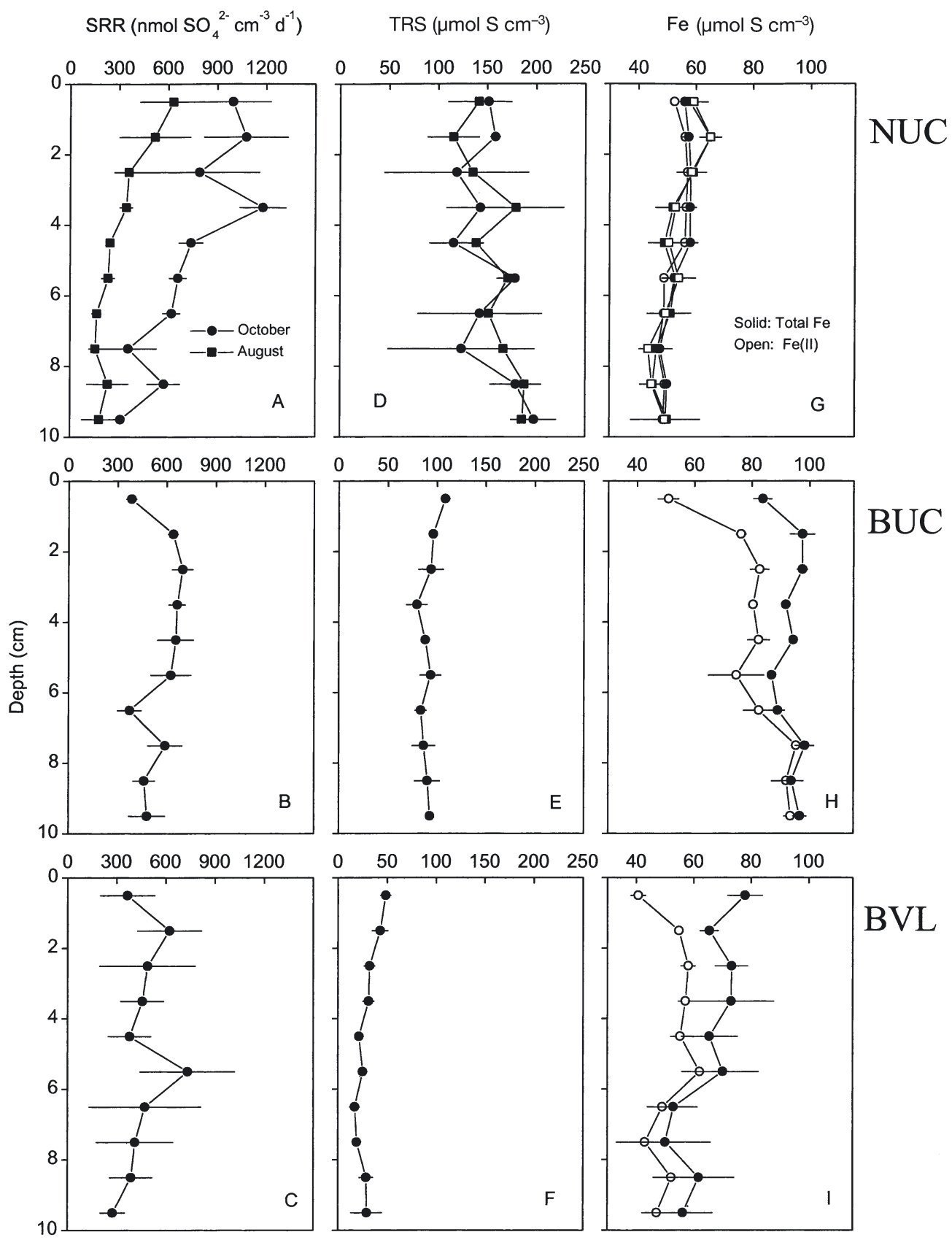

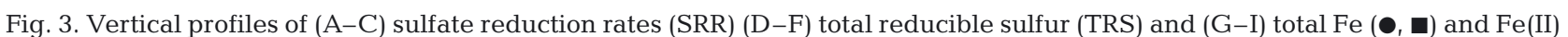
$(\mathrm{O}, \mathrm{\square})$ at nonbioturbated creek bank (NUC) in October 1999 and August 2000, and at bioturbated creek bank (BUC) and bioturbated vegetated levee (BVL) in October 1999 (Mean $\pm \mathrm{SD}, \mathrm{n}=3$ ). Values from October and August sampling periods are represented by circles and suares, respectively 
Table 3. Depth-integrated (0 to $10 \mathrm{~cm}$ ) sulfate reduction rates (SRR) and pools of total reducible sulfur (TRS) and reactive Fe(III) at non-bioturbated unvegetated creek bank (NUC), bioturbated unvegetated creek bank (BUC) and bioturbated vegetated levee $(B V L)($ mean $\pm S D, n=3)$; nd: not detected

\begin{tabular}{|c|c|c|c|c|}
\hline \multirow{2}{*}{ Parameter } & \multicolumn{3}{|c|}{ October 1999} & \multirow{2}{*}{$\begin{array}{c}\text { August } 2000 \\
\text { NUC }\end{array}$} \\
\hline & NUC & BUC & BVL & \\
\hline $\mathrm{SRR}\left(\mathrm{mmol} \mathrm{SO} \mathrm{S}^{-2} \mathrm{~m}^{-2} \mathrm{~d}^{-1}\right)$ & $73.0 \pm 5.5$ & $55.8 \pm 1.1$ & $45.0 \pm 19.5$ & $30.5 \pm 9.6$ \\
\hline TRS $\left(\mathrm{mol} \mathrm{S} \mathrm{m} \mathrm{m}^{-2}\right)$ & $15.1 \pm 2.2$ & $9.1 \pm 0.6$ & $2.9 \pm 0.6$ & $15.7 \pm 2.2$ \\
\hline Reactive Fe(III) (mol m²) & $0.17 \pm 0.10$ & $1.19 \pm 0.48$ & $1.27 \pm 0.50$ & nd \\
\hline
\end{tabular}

increasing depth in the sediment at NUC, whereas a slight decrease was observed at BUC and BVL (Fig. 3D-F). Depth-integrated (0 to $10 \mathrm{~cm}$ ) TRS pools showed a pattern similar to SRR, with highest $\left(15 \mathrm{~mol} \mathrm{~m}^{-2}\right)$ levels at NUC, intermediate levels $\left(9 \mathrm{~mol} \mathrm{~m}^{-2}\right)$ at BUC and lowest $\left(3 \mathrm{~mol} \mathrm{~m} \mathrm{~m}^{-2}\right)$ at BVL (Table 3). Total Fe decreased slightly with increasing depth at NUC and BVL, but increased at BUC. The concentration of amorphous Fe(III) oxides

$\mathrm{Fe}^{2+}$ accumulated to much higher (2.5 times) concentrations in the rhizosphere. The Fe(III) reduction rate was 4 times higher in the rhizosphere $\left(6.2 \pm 0.4 \mu \mathrm{mol} \mathrm{Fe} \mathrm{cm}{ }^{-3}\right.$ $\left.\mathrm{d}^{-1}\right)$ than in the bulk levee sediment $(1.7 \pm 0.5 \mu \mathrm{mol} F$ $\mathrm{cm}^{-3} \mathrm{~d}^{-1}$ ) (Fig. 5B).

\section{Solid-phase sulfur and iron}

TRS was comprised almost completely of chromiumreducible sulfide (95 to $100 \%$ ) at all sites (data not shown). TRS concentrations increased irregularly with (total $\mathrm{Fe}-\mathrm{Fe}[\mathrm{II}]$ ) exhibited the opposite picture, with highest concentrations at BVL $(19 \pm 5 \%$ of total $\mathrm{Fe})$, intermediate levels at BUC $(13 \pm 5 \%)$ and lowest levels at NUC ( $3 \pm 2 \%$ ) (Table 3 ). The concentration of Fe(III) gradually decreased with increasing depth from 15-20 to $<5 \mu \mathrm{mol} \mathrm{cm}{ }^{-3}$ (Fig. 3H,I). At NUC, where almost all iron $(>97 \%$ ) occurred as reduced Fe(II) (Fig. 3G), the total iron concentration was 17 and $42 \%$ lower than at BVL and BUC, respectively.

The TRS pool appeared relatively unaffected by the presence of burrows, resulting in a very slow sulfur turnover near burrow walls (Fig. 4C,D). Thus, turnover
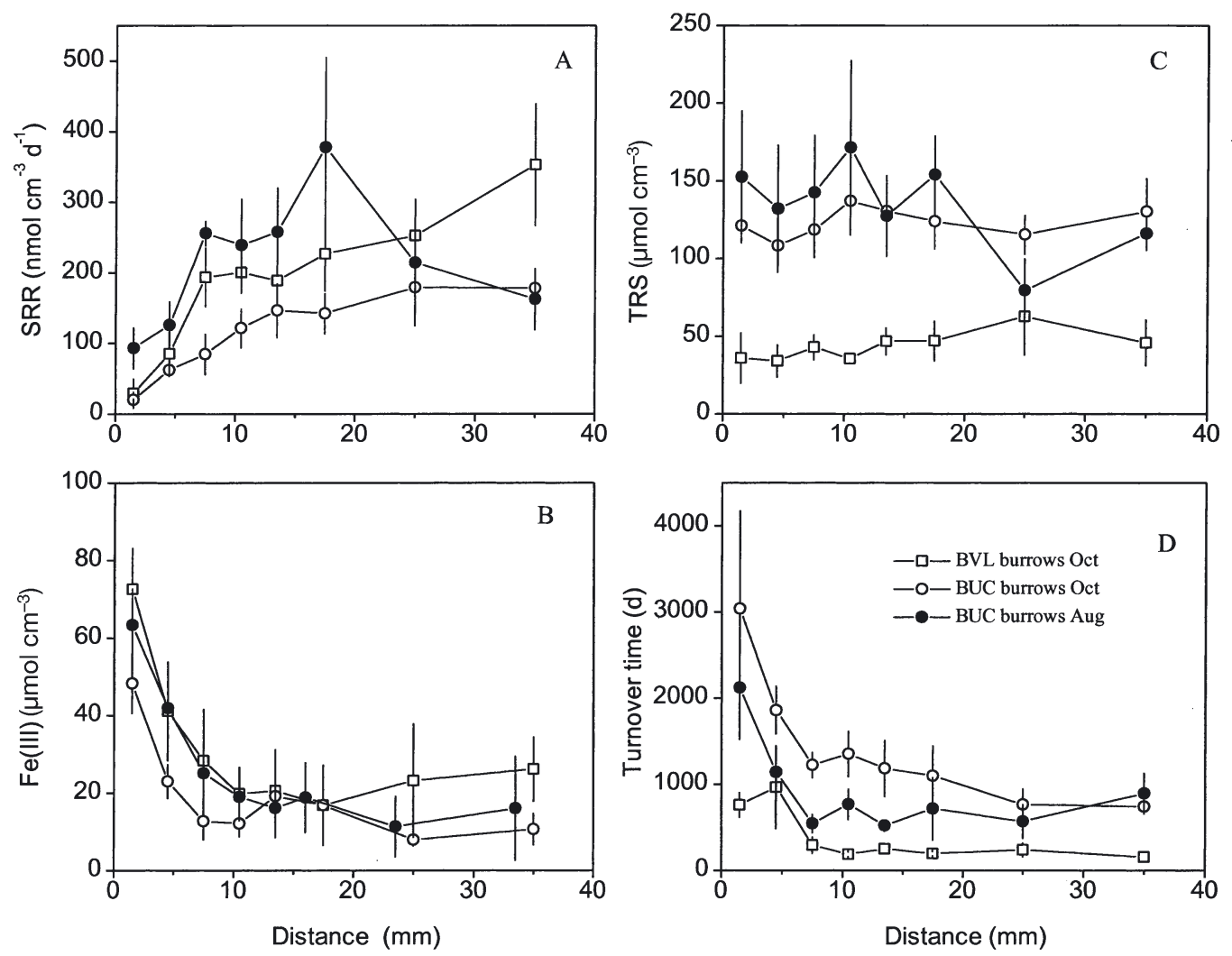

Fig. 4. Radial profiles of (A) sulfate reduction rates (SRR), (B) Fe(III) concentrations, (C) total reducible sulfur (TRS) and (D) turnover time of sulfur from Uca pugnax burrow walls into bulk sediment at $5 \mathrm{~cm}$ depth. Burrows were sampled at levee (BVL) in October 1999 and creek bank (BUC) in October 1999 and August 2000 (Mean \pm SD, n = 5), Distance = distance from burrow walls 

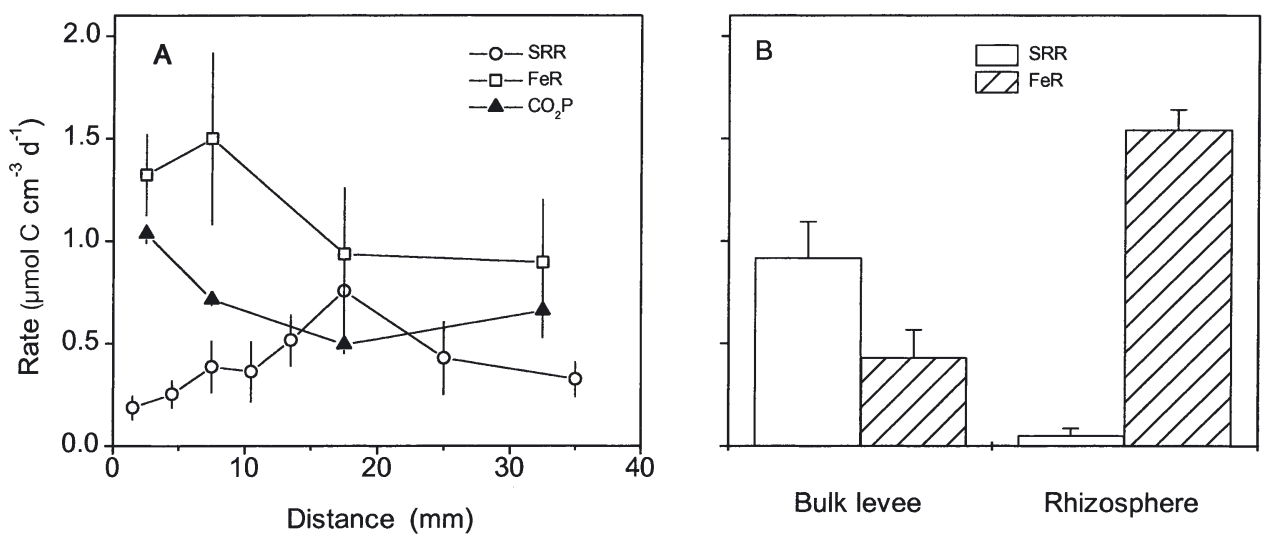

Fig. 5. (A) $\mathrm{CO}_{2}$ production rates $\left(\mathrm{CO}_{2} \mathrm{P}\right), \mathrm{SO}_{4}{ }^{2-}$ reduction rates (SRR) and $\mathrm{Fe}(\mathrm{III})$ reduction rates (FeR) as a function of distance from Uca pugnax burrow walls at the creek bank; (B) $\mathrm{SO}_{4}{ }^{2-}$ reduction rates (SRR) and Fe(III) reduction rates (FeR) in the bulk levee and through the rhizosphere in August 2000. $\mathrm{CO}_{2} \mathrm{P}$ and FeR were obtained from jar incubations (standard error determined from regression) while SRR was from ${ }^{35} \mathrm{~S}$ whole-core incubations (values are means $\pm \mathrm{SD} ; \mathrm{n}=3$ ). Rates are converted to $\mathrm{C}$ units by $\mathrm{C}: \mathrm{S}$ ratio of $2: 1$ and $\mathrm{Fe}: \mathrm{C}$ ratio of $4: 1$

time was 6 to 8 yr adjacent to BUC burrows, and about $2 \mathrm{yr}$ around BVL burrows compared with 2 and $0.2 \mathrm{yr}$, respectively, at a distance of 3 to $4 \mathrm{~cm}$. Total HClextractable $\mathrm{Fe}$ around burrows was similar to that in the bulk sediment at BVL, except for $30 \%$ higher values immediately adjacent to burrow walls (data not shown). Fe(III), on the other hand, was high around burrow walls at both sites and on both sampling occasions (Fig. 4B), and decreased rapidly with increasing distance from the walls. The Fe(III) content adjacent to the burrow walls was 2 to 3 times higher than 1 to $4 \mathrm{~cm}$ away from the walls and about 2 times higher than in surface sediment.

The TRS pool was low in the rhizosphere compared to bulk levee sediment. The total Fe content, on the other hand, was not significantly different from bulk sediment levels at the same depth, but almost all of the iron $(89 \%)$ in the rhizosphere was oxidized Fe(III) compared to only $19 \%$ in the bulk sediment (Table 4 ).

\section{Porewater chemistry}

Vertical profiles of $\mathrm{SO}_{4}{ }^{2-}$ ranged from 15 to $23 \mathrm{mM}$ at all sites in October with no specific depth pattern (Fig. 7A). However, a clear depth gradient from 28 to 30 to $18 \mathrm{mM} \mathrm{SO}_{4}{ }^{2-}$ was observed in the 4 to $7 \mathrm{~cm}$ depth interval at NUC in August. $\mathrm{Fe}^{2+}$ decreased rapidly with increasing depth at NUC and was not detectable below $3 \mathrm{~cm}$ depth (Fig. 7B), where dissolved sulfide started to accumulate (Fig. 7C). The Fe ${ }^{2+}$ gradient was steepest in October, while sulfide evolved most dramatically in August. At the 2 bioturbated sites, BUC and BVL, $\mathrm{Fe}^{2+}$ increased to subsurface maxima of $\sim 450$ and $\sim 570 \mu \mathrm{M}$, respectively, at 1 to $2 \mathrm{~cm}$ depth in October and remained high $(>130 \mu \mathrm{M})$ throughout the entire depth interval. No dissolved sulfide was detected at these sites. DOC increased gradually with increasing depth from 0.4 to $1.9 \mathrm{mM}$ (Fig. 7D), and was slightly but consistently higher at BVL than at the other sites. $\mathrm{TCO}_{2}$ accumulated with depth at all sites (Fig. 7E), with highest $\mathrm{TCO}_{2}$ concentrations observed at NUC in August and lowest at BUC in October.

While sulfate concentrations varied from 18 to $22 \mathrm{mM}$ with no specific pattern with distance from burrow walls (data not shown), dissolved $\mathrm{Fe}^{2+}$ showed low concentrations immediately adjacent to burrow walls, increasing to $\sim 100 \mu \mathrm{M}$ (October) and $\sim 350 \mu \mathrm{M}$ (August) with increasing distance (Fig. 8). The radial $\mathrm{TCO}_{2}$ profiles were almost similar at BUC and BVL (1 to $2 \mathrm{mM})$, showing a slight increase with distance from burrows walls (data not shown). All porewater

Table 4. Porewater and solid-phase concentrations in cross-sections through rhizosphere directly below Spartina alterniflora and through the bulk levee sediment between plants at $5 \mathrm{~cm}$ depth in October 1999 and August 2000 $($ mean $\pm \mathrm{SD}, \mathrm{n}=5$ )

\begin{tabular}{|lcccc|}
\hline \multirow{2}{*}{ Parameter } & \multicolumn{2}{c}{ Rhizosphere } & \multicolumn{2}{c|}{ Levee bulk } \\
& October & August & October & August \\
& & & & \\
& & & & \\
& & & \\
$\mathrm{CO}_{2}(\mathrm{mM})$ & $20.5 \pm 0.5$ & $0.9 \pm 0.1$ & $4.3 \pm 0.8$ & $2.9 \pm 0.6$ \\
$\mathrm{SO}_{4}{ }^{2-}(\mathrm{mM})$ & $30.6 \pm 2.2$ & $18.9 \pm 0.8$ & $26.8 \pm 1.3$ \\
$\mathrm{Fe}^{2+}(\mu \mathrm{M})$ & $196.0 \pm 171.9$ & $55.7 \pm 28.5$ & $493.7 \pm 137.9$ & $656.9 \pm 136.1$ \\
Total Fe $\left(\mu \mathrm{mol} \mathrm{cm}^{-3}\right)$ & $85.6 \pm 35.2$ & $130.8+8.0$ & $70.1 \pm 21.8$ & $86.6+8.6$ \\
$\mathrm{Fe}(\mathrm{III})\left(\mu \mathrm{mol} \mathrm{cm}^{-3}\right)$ & $86.4 \pm 30.7$ & $113.7+12.7$ & $8.0 \pm 10.9$ & $5.1+3.3$ \\
TRS $\left(\mu \mathrm{mol} \mathrm{cm}{ }^{-3}\right)$ & $13.5 \pm 20.0$ & $3.7 \pm 1.4$ & $21.5 \pm 7.8$ & $51.1 \pm 26.9$ \\
& & & & \\
\hline
\end{tabular}



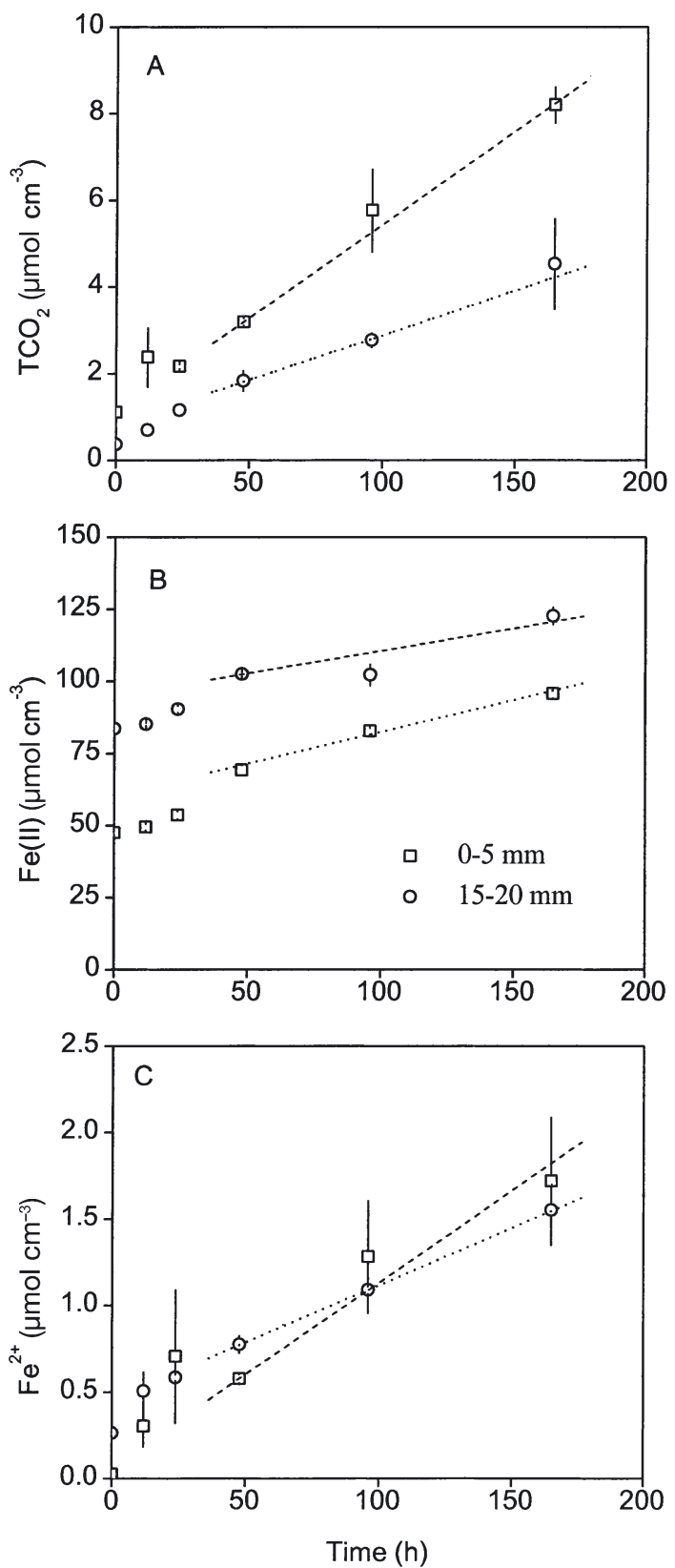

Fig. 6. Representative examples of changes in rates of (A) $\mathrm{CO}_{2}$ production, (B) Fe(II) accumulation and (C) dissolved $\mathrm{Fe}^{2+}$ accumulation from anaerobically incubated sediment sampled at 0 to 5 and 15 to $20 \mathrm{~mm}$ distance from creek-bank burrows of Uca pugnax in August. Results represent mean \pm range of duplicate samples sacrificed at each time point. Lines are drawn according to least-squares linear regression of the last 3 time points

constituents, except for $\mathrm{SO}_{4}{ }^{2-}$, were considerably lower in the rhizosphere than in the ambient sediment (Table 4). $\mathrm{TCO}_{2}$ in the rhizosphere only attained 16 and $31 \%$ of the bulk level in October and August, respectively. Porewater $\mathrm{Fe}^{2+}$ in the rhizosphere reached 40 and $8 \%$ of the concentrations in bulk sediment. Dissolved sulfide was not detectable by analysis or odor in any radial burrow and rhizosphere samples.

The average concentrations of most solutes in the burrow water were intermediate to those of creek water and sediment porewater. Thus, the $\mathrm{SO}_{4}{ }^{2-}$ concentration was $\sim 17 \mathrm{mM}$ in burrow water compared to $\sim 16 \mathrm{mM}$ for incoming and $\sim 20 \mathrm{mM}$ for outgoing creek water and sediment porewater (Table 5). Dissolved $\mathrm{Fe}^{2+}$ in burrows varied from 0 to $110 \mu \mathrm{M}$ at BUC and 0 to $86 \mu \mathrm{M}$ at BVL, with most replicates near the lower limit. The level of $\mathrm{TCO}_{2}$ in burrow water was within the range of that observed in the sediment porewater near burrow walls. Free sulfide was not detectable by odor in burrow water.

\section{DISCUSSION}

Previous research indicated that Fe(III) reduction and sulfate reduction should be considered the predominant microbial respiration processes coupled to organic carbon oxidation in saltmarsh sediments (Kostka et al. $2002 a, b)$. This previous work also showed the drastic effects that plant roots and crab burrows can have on sediment geochemical parameters (Kostka et al. $2002 a, b)$. In this study, we have further elucidated the effects of macrobenthic organisms on sediment biogeochemistry through radial profiling of the burrow wall and rhizosphere. Thus we confirm that the Fe cycle in saltmarsh sediments is stimulated by macrobenthic activity, leading to an increased supply of reactive Fe(III) which causes Fe(III) reduction to outcompete sulfate reduction during carbon oxidation.

Many previous studies have suggested that macrofauna and macrophytes substantially affect the geochemical cycles of S and Fe in marine sediments (e.g. Hines 1991, Kostka \& Luther 1995, Kostka et al. 2002b), but few experimental studies in saltmarshes have directly determined the biogeochemical effects of these macroorganisms in general, and their impact on the partitioning of the predominant carbon oxidation pathways (microbial Fe[III] reduction and sulfate reduction) in particular. In this study a spatial gradient in sulfate reduction activity was observed with macroorganism abundance, with highest rates at the uninhabited site, intermediate rates at the bioturbated site and lowest rates at the bioturbated, vegetated site. Solute and particle-mixing, mediated by rooted macrophytes and bioturbating macrofauna, enhance the Fe cycle in saltmarsh sediments. Rapid Fe cycling supports increased reactive Fe(III) concentrations thereby allowing Fe(III)-reducing bacteria to outcompete sulfate-reducing bacteria during carbon oxidation. 

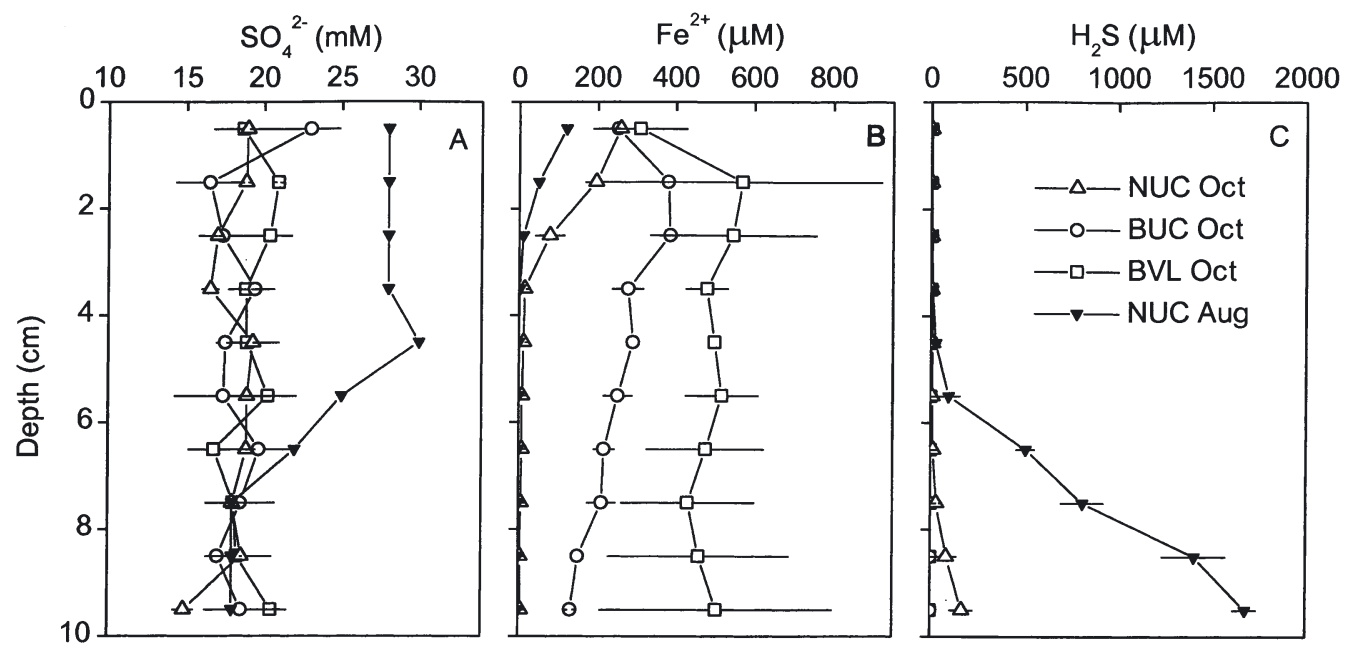

Fig. 7. Vertical profiles of porewater constituents at nonbioturbated creek bank (NUC) in October 1999 and August 2000, and at bioturbated creek bank (BUC) and bioturbated, vegetated levee (BVL) in October 1999 (Mean $\pm \mathrm{SD}, \mathrm{n}=3$ ). $\mathrm{TCO}_{2}=$ total carbon dioxide

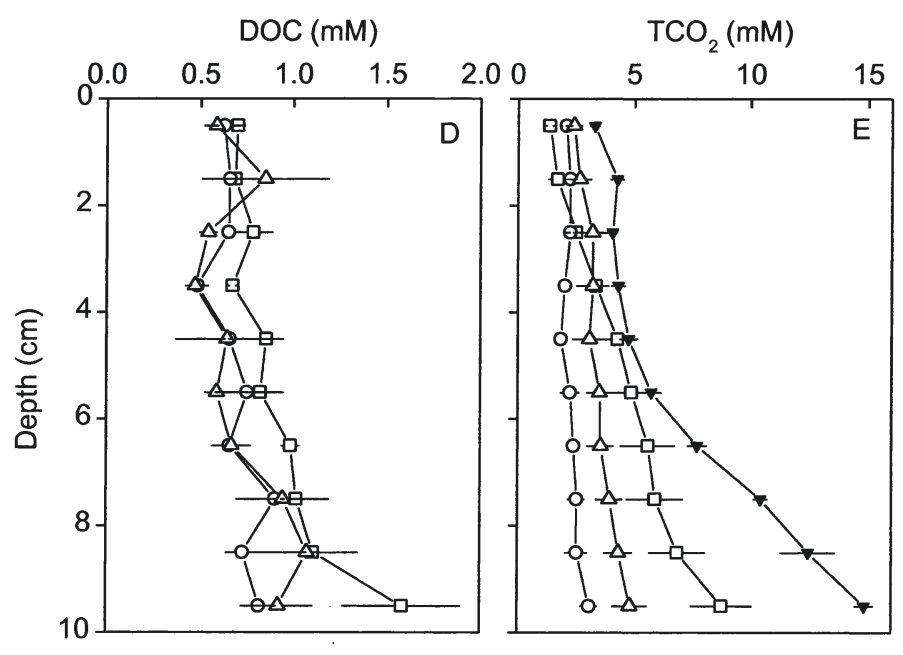

the sediment is progressively more oxidized near burrow walls. The high redox conditions strongly impede sulfate reduction and slow down the turnover of sulfur. Microbial Fe reduction clearly replaces sulfate reduction as the most important organic carbon oxidation pathway near burrow walls. Similar responses of sulfur dynamics in sediment directly surrounding burrow structures have been observed in burrows of various polychaetes, molluscs and in artificially irrigated burrows (Hansen et al. 1996, Chung \& King 1999, Nielsen et al. 2003). Burrowing and ventilation behavior, however, vary considerably among macrofauna, resulting in differences in the physical and chemical characteristics of burrows (Kristensen 1983a,b). Thus, enhanced SRR around

Given the high density of fiddler crabs in the Georgia marsh and their impact on sediment biogeochemistry, the potential influence on overall saltmarsh productivity and carbon dynamics is obvious. Highresolution radial profiles provide evidence that the direct impact of burrows is focused in a zone of 1 to $2 \mathrm{~cm}$ from the burrow wall. The radial profiles of porewater and solid phase constituents clearly show that

Table 5. Uca pugnax-burrow and creek-water chemistry October 1999. (n): number of replicates (mean $\pm \mathrm{SD}$ ). $\mathrm{TCO}_{2}$ : total carbon dioxide

\begin{tabular}{|lcccc|}
\hline Site & $(\mathrm{n})$ & $\begin{array}{c}\mathrm{SO}_{4}{ }^{2+} \\
(\mathrm{mM})\end{array}$ & $\begin{array}{c}\mathrm{Fe}^{2+} \\
(\mu \mathrm{M})\end{array}$ & $\begin{array}{l}\mathrm{TCO}_{2} \\
(\mathrm{mM})\end{array}$ \\
\hline BUC burrows & $(5)$ & $17.0 \pm 1.8$ & $38.6 \pm 19.7$ & $1.8 \pm 0.7$ \\
BVL burrows & $(20)$ & $17.1 \pm 1.9$ & $7.1 \pm 21.3$ & $3.6 \pm 1.1$ \\
Incoming creek & $(5)$ & $15.9 \pm 1.8$ & $1.1 \pm 0.6$ & $2.0 \pm 0.7$ \\
Outgoing creek & $(5)$ & $20.2 \pm 0.6$ & $1.1 \pm 0.7$ & $1.8 \pm 0.3$ \\
\hline
\end{tabular}

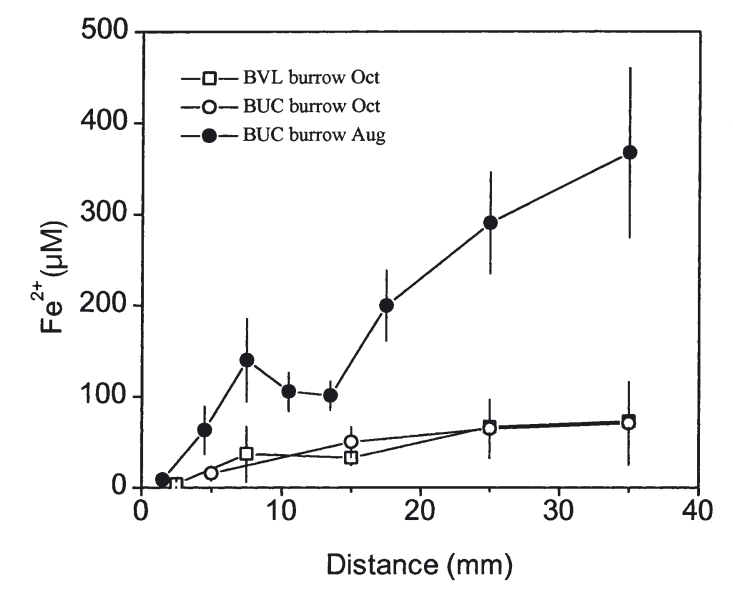

Fig. 8. Radial profiles of porewater $\mathrm{Fe}^{2+}$ from Uca pugnax burrow walls into bulk sediment at $5 \mathrm{~cm}$ depth. Burrows were sampled at levee (BVL) in October 1999 and creek bank (BUC) in October 1999 and August 2000 (Mean \pm SD, $\mathrm{n}=4$ to 5). Distance $=$ distance from burrow walls 
Table 6. Dissimilatory sulfate reduction rates (SRR), partitioning of chemical and biotic (dissimilatory) Fe reduction rates (FeR), Fe:C stoichiometry in jar incubations, and importance of Fe reduction to total carbon oxidation in sediment incubations from BUC Uca pugnax burrows, Spartina alterniflora rhizosphere and bulk levee (BVL) in August 2000. To facilitate direct comparison, rates are presented in $\mathrm{C}$ units assuming the theoretical stoichiometry of $\mathrm{C}: \mathrm{S}=2: 1$ and Fe:C $=4: 1$. SRR $={ }^{35} \mathrm{~S}$ whole core incubations assuming $\mathrm{C}: \mathrm{S}=2: 1$; Chemical $\mathrm{FeR}=$ potential $\mathrm{Fe}$ reduction due to abiotic reaction with $\mathrm{H}_{2} \mathrm{~S}$ from $\mathrm{SRR}$, assuming $\mathrm{H}_{2} \mathrm{~S}: \mathrm{FeOOH}=3: 2$; Total FeR $=$ Fe reduction rates from regression (Fig. 6B) assuming Fe:C = 4:1; Biotic FeR = proportion of Fe reduction ascribed to bacterial processes; $\mathrm{C}$-oxidation $=$ jar C-oxidation rates from regression (Fig. $6 \mathrm{~A}$ ); Fe:C ratio $=$ estimated Fe:C stoichiometry from jar rates when chemical $\mathrm{FeR}$ is subtracted; $\mathrm{C}$-oxidation = estimated $\mathrm{C}$-oxidation through biotic $\mathrm{SO}_{4}{ }^{2-}$ and $\mathrm{Fe}(\mathrm{III})$ reduction; $\mathrm{C}$-oxidation via $\mathrm{FeR}=\mathrm{C}$-oxidation through Fe reduction (total FeR) in \% of total

\begin{tabular}{|c|c|c|c|c|c|c|c|c|}
\hline $\begin{array}{l}\text { Distance from } \\
\text { burrow wall } \\
(\mathrm{mm})\end{array}$ & $\begin{array}{c}\mathrm{SRR} \\
\left(\mathrm{nmol} \mathrm{cm}{ }^{-3} \mathrm{~d}^{-1}\right)\end{array}$ & $\begin{array}{c}\text { Chemical } \\
\text { FeR } \\
\left(\mathrm{nmol} \mathrm{cm}{ }^{-3} \mathrm{~d}^{-1}\right)\end{array}$ & $\begin{array}{c}\text { Total } \\
\text { FeR } \\
\left(\mathrm{nmol} \mathrm{cm}{ }^{-3} \mathrm{~d}^{-1}\right)\end{array}$ & $\begin{array}{l}\text { Biotic } \\
\text { FeR } \\
(\%)\end{array}$ & $\begin{array}{c}\text { Measured } \\
\text { C-oxidation } \\
\left(\mathrm{nmol} \mathrm{cm} \mathrm{cm}^{-3} \mathrm{~d}^{-1}\right)\end{array}$ & $\begin{array}{l}\text { Estimated } \\
\text { Fe:C } \\
\text { ratio }\end{array}$ & $\begin{array}{c}\text { Estimated } \\
\text { C-oxidation } \\
\left(\mathrm{nmol} \mathrm{cm}^{-3} \mathrm{~d}^{-1}\right)\end{array}$ & $\begin{array}{c}\text { Estimated } \\
\text { C-oxidation } \\
\text { via FeR (\%) }\end{array}$ \\
\hline $0-5$ & 219 & 18 & 1323 & 98.6 & 1034 & 5.0 & 1524 & 86 \\
\hline $5-10$ & 387 & 32 & 1500 & 97.9 & 714 & 8.2 & 1854 & 79 \\
\hline $15-20$ & 756 & 63 & 935 & 93.3 & 495 & 7.1 & 1628 & 54 \\
\hline $30-35$ & 377 & 31 & 895 & 96.5 & 659 & 5.2 & 1241 & 70 \\
\hline Rhizosphere & 60 & 5 & 1544 & 99.7 & 456 & 13.5 & 1599 & 96 \\
\hline Levee bulk & 920 & 77 & 432 & 82.2 & 367 & 3.9 & 1275 & 28 \\
\hline
\end{tabular}

Mya arenaria burrows (Hansen et al. 1996) has been ascribed to substrate enrichment due to organic excretion from $M$. arenaria rather than to any ventilation or behavioral response. Chung \& King (1999) further substantiated that parameters other than ventilation determines the microbial activity in $M$. arenaria burrows. The limited or no change in particulate organic carbon and nitrogen content in Uca pugnax burrow walls, on the other hand, suggests that the increase in sediment surface area (controlling the flux of oxygen) is the driving force behind the specific geochemistry around $U$. pugnax burrows, while passive or active addition of carbon to the burrow wall (as mucus or particle displacement) is of minor importance.

The effect of fiddler crabs is also evident from the average sediment biogeochemistry in the upper $10 \mathrm{~cm}$ sediment column, although cores were taken at some distance from burrows. The higher oxidation level caused by fiddler crabs at BUC resulted in $25 \%$ lower average sulfate reduction compared to NUC. The corresponding higher average total $\mathrm{Fe}$ concentration and lower TRS at BUC than at NUC indicates enhanced pyrite oxidation at BUC due to translocation and/or formation of $\mathrm{Fe}(\mathrm{III})$ into anoxic sediment. Thus, solid Fe(III) was observed at all depths at BUC, while most Fe was reduced at NUC. A similar pattern of net reoxidation of TRS pools has been reported previously for other highly bioturbated sediments (Hansen et al. 1996, Banta et al. 1999, Kostka et al. 2002b).

Roots of marsh plants are efficient conduits of oxygen to the interior of the sediment because their welldeveloped aerenchyma system allows oxygen to diffuse from leaves to roots (Sundby et al. 1998, Holmer et al. 2002). Locally, Spartina alterniflora appears to have greater impact on the sediment biogeochemistry than fiddler crabs. All the extractable Fe in the rhizosphere comprised amorphous Fe-oxides, and Fe reduction rates were among the highest reported for marine sediments (Thamdrup 2000), whereas sulfate reduction was almost absent. A high content of iron oxides in the rhizosphere and massive iron-oxide coatings around roots has been described for other aquatic macrophytes (Sundby et al. 1998). On a marsh-wide scale, the relative importance of $S$. alterniflora roots versus fiddler crab burrows for sediment biogeochemistry depends on the relative size of sediment volume influenced by each macroorganism. At the SERF marsh, where roughly 10 and $25 \%$ of the marsh surface is occupied by creek bank and tall S. alterniflora zones, respectively (Kostka et al. 2002a), quantification of the sediment zones influenced by macroorganisms is currently being addressed. Fiddler crabs increase the marsh surface area by as much as 60\% (Katz 1980); hence the effects of fiddler crabs on $\mathrm{S}$ and Fe cycles may, on a marsh-wide scale, potentially match or even exceed those of $S$. alterniflora.

\section{Fe(III) reduction}

The lack of detectable $\mathrm{H}_{2} \mathrm{~S}$ in the upper $3 \mathrm{~cm}$ of the sediment at NUC or to $10 \mathrm{~cm}$ depth at the 2 other sites despite extensive sulfate reduction indicates rapid sulfide immobilization through reaction with dissolved iron in the sediment (Thamdrup \& Canfield 1996). $\mathrm{Fe}(\mathrm{III})$ reduction in the saltmarsh has long been considered an almost exclusively abiotic reaction with dissolved sulfide (Howarth 1993). However, recent studies have shown that microbial Fe(III) reduction coupled to carbon oxidation can be important in saltmarsh 
sediments (Luther et al. 1992, Jacobsen 1994, Kostka \& Luther 1995). In accordance with this, we found that $\mathrm{Fe}(\mathrm{III})$ reduction rates greatly exceeded the reduction potential of $\mathrm{H}_{2} \mathrm{~S}$ produced by sulfate reduction (Table 6). These results are in accordance with those of Kostka et al. (2002a), who found that microbial Fe reduction accounted for all carbon mineralization in bioturbated vegetated sediments at the same location. Using treatments with molybdate, formalin and pasteurization, Kostka et al. (2002a) confirmed that Fe(III) reduction is primarily a biologically catalyzed process.

Dissimilatory reduction of $1 \mathrm{~mol} \mathrm{SO}_{4}{ }^{2-}$ produces $1 \mathrm{~mol} \mathrm{H}_{2} \mathrm{~S}$, which potentially can reduce $2 / 3 \mathrm{~mol} \mathrm{Fe}$ (III) according to Eqs. (1) \& (2) below (Thamdrup \& Canfield 1996, Jørgensen 2000):

$$
\begin{gathered}
\mathrm{SO}_{4}{ }^{2-}+2 \mathrm{CH}_{2} \mathrm{O} \rightarrow \mathrm{H}_{2} \mathrm{~S}+2 \mathrm{HCO}_{3}{ }^{-} \\
3 \mathrm{H}_{2} \mathrm{~S}+2 \mathrm{FeOOH} \rightarrow \mathrm{S}^{0}+2 \mathrm{FeS}+4 \mathrm{H}_{2} \mathrm{O}
\end{gathered}
$$

Accordingly, $\mathrm{H}_{2} \mathrm{~S}$ produced by SRR near BUC burrows can only account for $<7 \%$ of the total Fe(III) reduction. The accumulation of $\mathrm{Fe}^{2+}$ in the present jarincubations supports the contention that $\mathrm{H}_{2} \mathrm{~S}$ production by SRR is well below the oxidation capacity of Fe(III). More than $99 \%$ of the Fe(III) reduction in the rhizosphere and $82 \%$ in the bulk levee must therefore be ascribed to dissimilatory microbial reduction.

Dissimilatory reduction of $4 \mathrm{~mol}$ of $\mathrm{Fe}(\mathrm{III})$ is coupled to $1 \mathrm{~mol}$ of $\mathrm{C}$ oxidation according to:

$$
4 \mathrm{FeOOH}+\mathrm{CH}_{2} \mathrm{O}+7 \mathrm{H}^{+} \rightarrow 4 \mathrm{Fe}^{2+}+\mathrm{HCO}_{3}^{-}+6 \mathrm{H}_{2} \mathrm{O}
$$

By correcting the total $\mathrm{Fe}(\mathrm{III})$ reduction for the potential chemical reduction and total carbon oxidation for the contribution by SRR, the stoichiometry of dissimilatory $\mathrm{Fe}$ reduction coupled to carbon oxidation $(\mathrm{Fe}: \mathrm{C})$ in burrow profiles at BUC was 5.0 to 8.2 , while ratios of 13.5 and 3.9 were observed in the rhizosphere and bulk levee, respectively at BVL (Table 6). The small size of the jars used, and consequently the limited volume of porewater obtained for analysis may have affected the precision of the method due to loss of $\mathrm{CO}_{2}$ during handling of samples, preferentially in the low $\mathrm{pH}$ rhizosphere sediment at $\mathrm{BVL}$. The $\mathrm{Fe}: \mathrm{C}$ ratios may also have been affected by the abiotic reduction of Fe(III) by organic ligands (Luther et al. 1992, 1996), particularly close to burrow walls and in the rhizosphere. The predicted 4:1 stoichiometry of Fe reduction was, however, confirmed in simultaneous incubations of larger sediment volumes from the rhizosphere by Kostka et al. (2002a).

\section{Dependence on Fe(III) concentrations}

Dissimilative Fe reduction in sediments is highly dependent on the presence of poorly crystalline Fe-oxides
(Thamdrup 2000) and the availability of labile organic carbon. Reoxidation of Fe(II) mediated by bioturbation and root action in iron-rich saltmarsh sediments can sustain very high rates of microbial Fe reduction. If all carbon oxidation around burrow walls is driven by sulfate and $\mathrm{Fe}$ (III) reduction, and the theoretical stoichiometries of $\mathrm{S}: \mathrm{C}=0.5$ and $\mathrm{Fe}: \mathrm{C}=4$ are valid, dissimilatory reduction of amorphous $\mathrm{Fe}$ (III) (16 to $\left.53 \mu \mathrm{mol} \mathrm{cm}^{-3}\right)$ is responsible for 54 to $86 \%$ of the total C-oxidation (Table 6). In the rhizosphere, where Fe(III) concentrations are extremely high $\left(114 \mu \mathrm{mol} \mathrm{cm}^{-3}\right)$, virtually all the microbial carbon mineralization is due to Fe(III) reduction, while only $28 \%$ can be ascribed to Fe(III) reduction in the less Fe(III)-rich $\left(5 \mu \mathrm{mol} \mathrm{cm}^{-3}\right)$ bulk levee sediment (Table 6 ). The contribution of Fe(III) reduction to the total C-oxidation in the marsh sediment is closely related to the concentration of amorphous Fe(III) (Fig. 9). The observed relationship agrees closely with the patterns previously observed for a range of subtidal marine sediments (Thamdrup 2000, Jensen et al. 2003), and described by Jensen et al. (2003) by the empirical function:

$$
\% \mathrm{FeR}=100 \% \times\left(1-\mathrm{e}^{-([\mathrm{Fe}(\mathrm{III})] \times 0.056)}\right)
$$

where $\% \mathrm{FeR}$ is the carbon oxidation through iron reduction in \% of total carbon oxidation and $\mathrm{Fe}(\mathrm{III})$ is the concentration of poorly crystalline Fe oxides, suggesting this to be a universal relationship. Thus, the importance of $\mathrm{Fe}(\mathrm{III})$ respiration is strongly dependent on Fe(III) concentrations below levels of $30 \mu \mathrm{mol}$ $\mathrm{cm}^{-3}$, while almost all anaerobic carbon oxidation at higher $\mathrm{Fe}(\mathrm{III})$ concentrations is mediated by $\mathrm{Fe}(\mathrm{III})$ reduction.

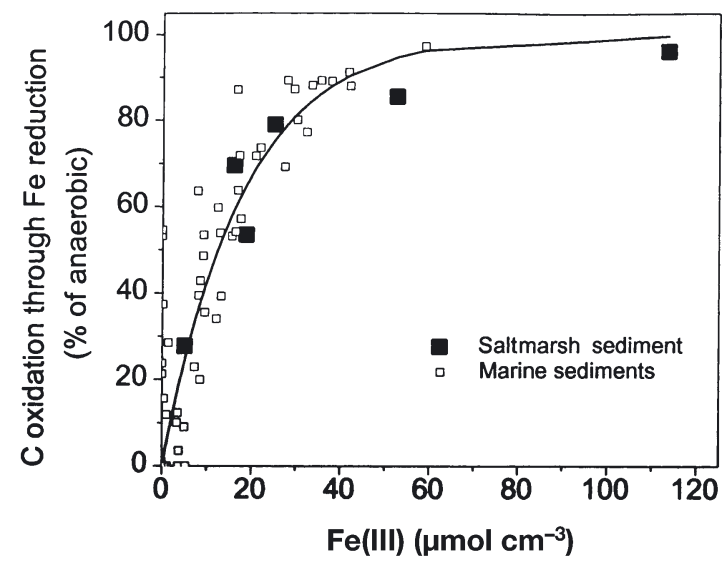

Fig. 9. Relative contribution of dissimilatory Fe(III) reduction to carbon oxidation as a function of the concentration of amorphous Fe(III) in the saltmarsh sediment incubations and in several marine locations (after Thamdrup 2000 and Jensen et al. 2003). Curve represents function $\% \mathrm{FeR}=100 \% \times$ $\left(1-\mathrm{e}^{-([\mathrm{Fe}(\mathrm{III})] \times 0.056)}\right)$. Sulfate reduction accounts for remaining

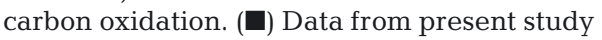




\section{Other C-oxidation pathways}

It must be emphasized that the importance of electron acceptors other than $\mathrm{S}$ and $\mathrm{Fe}$ has been ignored in the above discussion. The utilization of oxidized manganese as an electron acceptor for bacterial respiration in saltmarsh sediments is considered negligible, because manganese oxides are readily reduced chemically by (e.g.) Fe(II) and are therefore not available to bacteria (Howarth 1993). Denitrification due to nitrate limitation in saltmarsh sediments is also considered negligible. Nitrate concentrations never exceeded 10 to $12 \mu \mathrm{M}$ at the SERF location in October (J. E. Kostka unpubl.). It is not possible, however, to measure rates of aerobic respiration directly in saltmarsh sediments, since oxygen is utilized both in aerobic respiration and for oxidation of reduced metabolites like sulfide and $\mathrm{Fe}(\mathrm{II})$. Both bioturbation and oxygen leakage from roots clearly injects oxygen into the marsh sediment, and aerobic respiration must be of some importance, especially when the sediment is exposed to air at low tide. However, recent microelectrode profiles in the SERF marsh indicated that oxygen is absent within the first few millimeters depth of the sediment surface or next to macrofaunal burrows (Y. Furukawa et al. unpubl. results), and the quantitative importance of oxygen for total carbon oxidation has been found to be relatively low in other intertidal sediments. Thus, Kristensen et al. (2000) estimated that aerobic respiration is responsible for 6 to $65 \%$ of the carbon oxidation in vegetated and bioturbated mangrove sediments, while Mackin \& Swider (1989) found less than $15 \%$ in Long Island saltmarsh sediment. Thus, based on the existing evidence, anoxic mineralization processes must predominate in SERF marsh sediments.

Acknowledgements. We thank S. Matzen and D. Dalton for technical assistance. This research was supported by the EU research program 'Preserving the Ecosystem' under the ISLED project Contract ENV4-CT97-0582 (ELOISE contribution no. 358/17) and grant no. 9901749 from the Danish National Research Council.

\section{LITERATURE CITED}

Alongi DM (1998) Coastal ecosystem processes. CRC Press, New York, p 43-92

Banta G, Holmer M, Jensen MH, Kristensen E (1999) Effects of two polychaete worms, Nereis diversicolor and Arenicola marina, on aerobic and anaerobic decomposition in a sandy marine sediment. Aquat Microb Ecol 19: 189-204

Bertness MD (1985) Fiddler crab regulation of Spartina alterniflora production on a New England saltmarsh. Ecology 66:1042-1055

Chung WK, King GM (1999) Biogeochemical transformations and potential polyaromatic hydrocarbon degradation in macrofaunal burrow sediments. Aquat Microb Ecol 19: 285-295

Cline JD (1969) Spectrophotometric determinations of hydrogen sulfide in natural waters. Limnol Oceanogr 14: $454-458$

Fossing H, Jørgensen BB (1989) Measurement of bacterial sulfate reduction in sediments: evaluation of a single-step chromium reduction method. Biogeochemistry 8:205-222

Gribsholt B, Kristensen E (2002a) Effects of bioturbation and plant roots on saltmarsh bioturbation: a mesocosm study. Mar Ecol Prog Ser 241:71-87

Gribsholt B, Kristensen E (2002b) Impact of sampling methods on sulfate reduction rates and dissolved organic carbon (DOC) concentrations in saltmarsh sediment. Wetlands Ecol Manag 10:371-379

Gribsholt B, Kristensen E (2003) Benthic metabolism and sulfur cycling along an inundation gradient in a tidal Spartina anglica saltmarsh. Limnol Oceanogr (in press)

Giblin AE, Howarth RW (1984) Porewater evidence for a dynamic sedimentary iron cycle in saltmarshes. Limnol Oceanogr 29:47-63

Hall P, Aller RC (1992) Rapid, small-volume, flow injection analysis for $\Sigma \mathrm{CO}_{2}$ and $\mathrm{NH}_{4}{ }^{+}$in marine and freshwaters. Limnol Oceanogr 37:1113-1119

Hansen K, King GM, Kristensen E (1996) Impact of the softshell clam Mya arenaria on sulfate reduction in an intertidal sediment. Aquat Microb Ecol 10:181-194

Hansen JW, Udy JW, Perry CJ, Dennison WC, Lomstein BA (2000) Effect of the seagrass Zostera capricorni on sediment microbial processes. Mar Ecol Prog Ser 199:83-96

Hines ME (1991) The role of certain infauna and vascular plants in the mediation of redox reactions in marine sediments. In: Berthelin J (ed) Diversity of environmental biogeochemistry, Vol. 6, Elsevier Science BV, Amsterdam, p 275-286

Hines ME, Knollmeye SL, Tugel J (1989) Sulfate reduction and other sedimentary biogeochemistry in a northern New England saltmarsh. Limnol Oceanogr 34:578-590

Hines ME, Evans RS, Genthner BRS, Willis SG, Friedman S, Rooney-Varga JN, Devereux R (1999) Molecular phylogenetic and biogeochemical studies of sulfate-reducing bacteria in the rhizosphere of Spartina alterniflora. Appl Environ Microbiol 65:2209-2216

Holmer $M$, Andersen FØ, Holmboe N, Kristensen E, Thongtham N (1999) Transformation and exchange processes in the Bangrove mangrove forest-seagrass bed system, Thailand. Seasonal and spatial variations in benthic metabolism and sulfur biogeochemistry. Aquat Microb Ecol 20:203-212

Holmer M, Gribsholt B, Kristensen E (2002) Effects of sea level rise on growth of Spartina anglica and oxygen dynamics in rhizosphere and saltmarsh sediments. Mar Ecol Prog Ser 225:197-204

Howarth RW (1993) Microbial processes in salt-marsh sediments. In: Ford TE (ed) Aquatic microbiology. An ecological approach. Blackwell Scientific Publications, Boston, p 239-259

Howes BL, Howarth RW, Teal JM, Valiela I (1981) Oxidationreduction potentials in a saltmarsh: spatial patterns in interactions with primary production. Limnol Oceanogr 26:350-360

Isaksen MF, Finster K (1996) Sulphate reduction in the root zone of the seagrass Zostera noltii on the intertidal flats of a coastal lagoon (Arcachon, France). Mar Ecol Prog Ser 137:187-194

Jacobson ME (1994) Chemical and biological mobilization of $\mathrm{Fe}(\mathrm{III})$ in marsh sediments. Biogeochemistry 25:41-60 
Jensen MM, Thamdrup B, Rysgaard S, Holmer M, Fossing H (2003) Rates and regulation of microbial iron reduction in sediments of the Baltic-North Sea transition. Biogeochemistry (in press)

Jørgensen BB (1978) A comparison of methods for quantification of bacterial sulfate reduction in coastal marine sediments. Geomicrobiol J 1:11-27

Jørgensen BB (2000) Bacteria and marine biogeochemistry. In: Schulz HD, Zabel M (eds) Marine geochemisty. Springer-Verlag, New York, p 173-207

Katz LC (1980) Effects of burrowing by the fiddler crab, Uca pugnax (Smith). Estuar Coast Mar Sci 11:233-237

King GM, Garey MA (1999) Ferric iron reduction by bacteria associated with the roots of freshwater and marine macrophytes. Appl Environ Microbiol 65:4393-4398

Kostka JE, Luther GW (1994) Partitioning and speciation of solid phase iron in saltmarsh sediments. Geochim Cosmochim Acta 58:1701-1710

Kostka JE, Luther GW (1995) Seasonal cycling of Fe in saltmarsh sediments. Biogeochemistry 29:159-181

Kostka JE, Gribsholt B, Petrie E, Dalton D, Skeleton H, Kristensen E (2002a) The rates and pathways of carbon oxidation in bioturbated saltmarsh sediments. Limnol Oceanogr 47:230-240

Kostka JE, Roychoudhury A, Van Cappellen P (2002b) Rates and controls of anaerobic microbial respiration across spatial and temporal gradients in saltmarsh sediments. Biogeochemistry 60:40-76

Krantzberg G (1985) The influence of bioturbation on physical and biological parameters in aquatic environments: a review. Environ Pollut 39:99-122

Kristensen E (1983a) Ventilation and oxygen uptake by three species of Nereis (Annelida: Polychaeta). I. Effects of hypoxia. Mar Ecol Prog Ser 12:289-297

Kristensen E (1983b) Ventilation and oxygen uptake by three species of Nereis (Annelida: Polychaeta). II. Effects of temperature and salinity changes. Mar Ecol Prog Ser 12: 299-306

Kristensen E, Andersen FØ (1987) Determination of organic carbon in marine sediments: a comparison of two CHNanalyzer methods. J Exp Mar Biol Ecol 109:15-23

Kristensen E, Andersen FØ, Holmboe N, Holmer M, Thongtham N (2000) Carbon and nitrogen mineralisation in the sediments of the Bangrong mangrove area, Phuket, Thailand. Aquat Microb Ecol 22:199-213

Kristensen E, Holmer M (2001) Decomposition of plant materials in marine sediment exposed to different electron acceptors $\left(\mathrm{O}_{2}, \mathrm{NO}_{3}^{-}\right.$, and $\left.\mathrm{SO}_{4}{ }^{2-}\right)$, with emphasis on substrate origin, degradation kinetics, and the role of bioturbation. Geochim Cosmochim Acta 65:419-433

Levin LA, Talley TS (2000) Influence of vegetation and abiotic

Editorial responsibility: Otto Kinne (Editor),

Oldendorf/Luhe, Germany environmental factors on saltmarsh invertebrates. In Weinstein MP, Kreeger DA (eds) Concepts and controversies in tidal marsh ecology. Kluwer Academic Publishers, Dordrecht, p 661-707

Lowe KL, DiChristina TJ, Roychoudhury A, Van Cappellen P (2000) Microbiological and geochemical characterization of microbial $\mathrm{Fe}(\mathrm{III})$ reduction in saltmarsh sediments. Geomicrobiol J 17:163-178

Luther GW, Kostka JE, Church TM, Sulzberger B, Stumm W (1992) Seasonal iron cycling in the salt-marsh sedimentary environment: the importance of ligand complexes with $\mathrm{Fe}(\mathrm{II})$ and $\mathrm{Fe}(\mathrm{III})$ in the dissolution of $\mathrm{Fe}(\mathrm{III})$ minerals and pyrite, respectively. Mar Chem 40:81-103

Luther GW, Shellenbarger PA, Brendel PJ (1996) Dissolved organic Fe(III) and Fe (II) complexes in saltmarsh porewaters. Geochim Cosmochim Acta 60:951-960

Mackin JE, Swider KT (1989) Organic-matter decomposition pathways and oxygen-consumption in coastal marine sediments. J Mar Res 47:681-716

Mitsch JM, Gosselink JG (1993) Wetlands. Van Nostrand Reinhold, New York

Montague CL (1982) The influence of fiddler crab burrows and burrowing on metabolic processes in saltmarsh sediment. In: Kennedy VS (ed) Estuarine comparisons. Academic Press, New York, p 283-301

Nielsen LB, Finster K, Welsh DT, Donelly A, Herbert RA, de Wit R, Lomstein BA (2001) Sulphate reduction and nitrogen fixation rates associated with roots, rhizomes and sediments from Zostera noltii and Spartina maritima meadows. Environ Microbiol 3:63-71

Nielsen OI, Kristensen E, Holmer M (2003) Impact of Arenicola marina (Polychaeta) on sediment sulfur dynamics. Aquat Microb Ecol 33:95-105

Stookey LL (1970) Ferrozine-a new spectrophotometric reagent for iron. Analyst Chem 42:779-781

Sundby B, Vale C, Cacador I, Catarino FM, Madureira MJ, Caetarino F (1998) Metal-rich concentrations on the roots of saltmarsh plants: mechanism and rate of formation. Limnol Oceanogr 43:245-252

Tabatabai MA (1974) A rapid method for determination of sulfate in water samples. Environ Lett 7:237-243

Taylor DI, Allanson BR (1993) Impact of dense crab populations on carbon exchanges across the surface of a saltmarsh. Mar Ecol Prog Ser 101:119-129

Thamdrup B (2000) Bacterial manganese and iron reduction in aquatic sediments. In: Schink B (ed) Advances in microbial ecology. Kluwer Academic/Plenum Publishers, New York, p 41-84

Thamdrup B, Canfield DE (1996) Pathways of carbon oxidation in continental margin sediments off central Chile. Limnol Oceanogr 41:1629-1650

Submitted: December 12, 2002; Accepted: April 23, 2003

Proofs received from author(s): August 29, 2003 